Using problem-based learning in a micro-teaching course to develop EFL student teachers' reflective thinking and attitudes towards the course

\author{
Dr. Ahmed M.M.Abdelhafez*
}




\section{Using problem-based learning in a micro-teaching course to develop EFL student teachers' reflective thinking and attitudes towards the course}

Dr. Ahmed M.M.Abdelhafez*

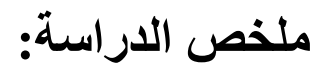

هدفت الدراسة إلى تحديد أثر التعلم القائم على المشكلات أثناء تدريس مقرر التنريس المصغر لطلاب

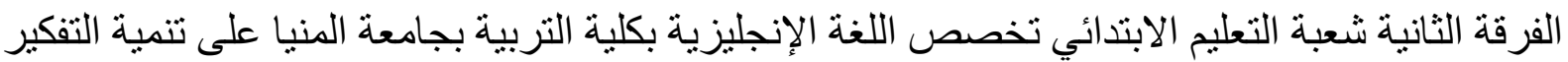

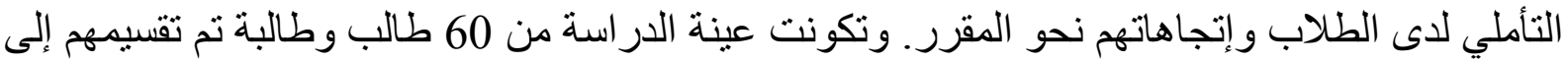
مجمو عتين أحدهما تجريبية والأخرى ضابطة واعتمدت منهجية الدراسة على التصميم شبه التجريبي. وقام الباحث بتصميم أداتا القياس و هما اختبار التفكير التأملي ومقياس الإتجاه وتم التحقق من صدق وثنات الأدوات. وكثفت نتائج الدراسة عن وجود فرق ذو دلالة إحصائية عند مستوى (0,05) بين متوسطات درجات المجموعتين التجريبية والضابطة لصالح المجموعة التجريبية في القياس البعدي لاختبار التفكير التأملي ، في حين لم يوجد فرق دال إحصائيا في مقياس الإتجاه وإن كانت النتائج قد أظهرت أن الطلاب في كلتا المجموعتين التجرييية والضابطة قد أظهرا إتجاهات إيجابية نحو مقرر التنريس المصغر. وتم تفسير ومناقثنة النتائج على ضوء الدراسات السابقة مع التأكيد على أهمية التفكير التأملي لما له من دور وسيط في تقريب الفجوة بين النظرية و التطبيق في بر امج إعداد معلم اللغة الإنجليزية كلغة أجنبية.

الكلمات المفتاحية

التعلم القائم على المشكلات ـ التفكير التأملي ـ التدريس المصغر ـ المعلمين الطلاب ـ اللغة الإنجليزية كلغة أجنبية - الإتجاهات 


\section{Abstract :}

The aim of the study was to identify the effect of using problem-based learning in a Micro-teaching course on developing EFL student teachers' reflective thinking and attitudes towards the course. The sample of the study consisted of sixty EFL student teachers in two groups, thirty for each group. The quasi- experimental research design was followed with one of the two groups as an experimental group and the other as a control one. A reflective thinking test and an attitude scale were designed by the researcher and used to collect data. The findings of the study revealed a statistically-significant difference at the level of (0.05) between means of scores of the experimental and control groups in the reflective thinking post-test in favor of the experimental group. However, no statistically significant difference was found in relation to the student teachers' attitudes as both the experimental and control groups had positive attitudes towards the course. The findings were discussed in light of the previous literature highlighting a mediating role of reflective thinking in bridging the gap between theory and practice in EFL teacher education programs.

\section{Key words:}

Problem-based learning, reflective thinking, micro-teaching, EFL student teachers, attitudes 


\section{Introduction:}

Previous literature indicates that there is a major lack of reflection among preservice teachers. In a review of literature, Rieger et al. (2013) noted that most of the studied preservice teachers perceived their teaching as an act of transferring acquired knowledge to their students with little or no regard for what they made of it. Furthermore, Rieger et al. (2013) highlighted that most preservice teachers were inexperienced at knowing how to engage in meaningful reflection, and some preservice teachers might find reflection a challenging and even painful practice that could question their preconceived beliefs and assumptions.

In the area of teaching English as a foreign language, the need and value of research on preservice teachers' reflective thinking were highlighted. Gungor (2016), in a study of EFL pre-service teachers' reflective practices in teaching English to young learners, asserted that preservice teachers were not able to use knowledge gained in educational courses to reflect onto real teaching settings in the practicum that subsequently followed in a way that created a gap, difficult to bridge, between theoretical considerations and the realities of teaching practice. Furthermore, Lee (2007), in a study of EFL preservice teachers in Hong Kong, pointed out that through reflection, pre-service teachers became more aware of themselves as would-be teachers and of the pedagogical context that impinged directly on teaching and learning. Lee asserted that in order to help pre-service teachers develop into reflective practitioners, reflection was a skill that had to be fostered from the beginning of the learning-to-teach process.

Sulistiyo (2015), in a study of EFL student teachers in Indonesia, highlighted the need of student teachers to reflect on teaching practice to be able to theorize the 
effect of that practice on learners in a way that could lead to changes in practice and the implementation of subsequent actions based on this theorizing. Komur (2010) demonstrated that the student teachers, in his study of preservice English teachers, were often aware of the state of their situation in real classroom teaching, and, upon reflection, could develop strategies to cope with the problems and challenges of teaching the target language. He concluded that 'the teaching knowledge and practice in teaching dichotomy should be investigated in depth by using different variables and contexts' p.(292). Similarly, Zhu (2014) called for more research to be carried out on student teachers' reflection given that 'the number of systematic researches about reflective thinking on TEFL classroom discourse is rather limited' (p.1275). The above-mentioned evidence justifies the need for the current study on EFL student teachers' reflective thinking, which is, arguably, a significant variable in mediating the influences of theory and practice of teaching on EFL preservice teachers' growth and development.

It is always reported that student teachers find it difficult to link practice to theory and lack pedagogical knowledge to be able to reflect (Leijen et al., 2014). Therefore, it has become necessary that research efforts focus on experiencebased approaches that could enable pre-service teachers to become self-aware of their knowledge and encourage them to develop reflective thinking.

Problem-based approaches to learning have a long history of advocating experience-based education and offer the potential to help students become reflective and flexible thinkers who can use knowledge to take action (HmeloSilver, 2004). Similarly, Rieger et al. (2013) argue that various practices, including problem-solving formats, can help preservice teachers become more comfortable with reflection. 
Hmelo-Silver (2004) points out the relationship between Problem Based Learning (PBL henceforth) and reflection. Accordingly, PBL incorporates reflection in several ways. Students periodically reflect on the adequacy of the ideas and knowledge relative to a problem or a learning issue in their field. At the completion of a problem, students reflect on what they have learned, how well they collaborated with the group, and how effectively they directed their learning. The reflection process in PBL is designed to help students identify gaps in their thinking; and transfer their problem-solving strategies, self-directed learning strategies, and knowledge to new situations.

Hmelo-Silver (2004) identified five goals of PBL including helping students develop 1) flexible knowledge, 2) effective problem-solving skills, 3) selfdirected learning skills, 4) effective collaboration skills, and 5) intrinsic motivation. De Simone (2008) points out that PBL is useful to prospective teachers in two ways: (a) the PBL process helps prospective teachers develop a broader, more principled understanding of classroom and pedagogical issues, and (b) PBL lets prospective teachers create a rich foundation for solving similar or more serious problems in the classroom.

According to Bereiter and Scardamalia (2006), PBL 'engages students in solving problems modeled as closely as possible on problems they will actually encounter in their professional practice' ( $p$ 703). They differentiate it from project-based learning. 'Unlike project-based learning, there is little focus on a tangible end product. The end product is a problem solution - a purely conceptual artifact' (ibid). Harrison (2008) highlights that problem cases simulate real-life classroom decision making including considering multiple perspectives, warranting solutions, assessing consequences, and reflecting on decisions. Thus, PBL could facilitate reflective practice. 


\section{Reflective thinking}

Teacher education programs have long been concerned with reflective practice to facilitate professional growth and equip prospective teachers with essential skills and disposition to become ready for their future profession. According to Leijen et al. (2014), 'Teacher reflection has been considered a dominant activity for developing practical knowledge and linking it with educational theories in teacher training programs' (p.315). Mirzaei et al. (2014) add that 'The central goal of reflective teacher education is to develop teachers' reasoning about why they employ certain instructional strategies and how they can improve their teaching to have a positive effect on students' (p.641).

Reflective thinking in education has originated as early as the start of the $20^{\text {th }}$ century with Dewey's books on The relationship of theory to practice in education, How we think, and Experience and education (Rodgers, 2002). According to Benammar (2004), reflection can generally be defined as a cognitive process carried out in order to learn from experiences through individual inquiry and collaboration with others. Benammar (2004) highlights that for teachers to act consciously, they need conscious thinking. Similary, Husu et al. (2008) highlight the conscious elements of reflection as follows:

Reflection is commonly reported as a process of self-examination and selfevaluation that teachers should engage in regularly in order to interpret and improve their professional practices. The argument goes that by thinking carefully about what is taking place in a given situation, teachers are better able to identify the options available. It presupposes that the process of reflection highlights a teacher's conscious choices about how to act in the classroom (p.38). 
Rodgers (2002), based on close analysis of Dewey's model of reflective teaching practice has distilled four essential characteristics of reflection. Accordingly, reflection (a) is a meaning-making process that moves a learner from one experience into the next with deeper understanding of its relationships with and connections to other experiences and ideas, (b) is a systematic, rigorous, disciplined way of thinking, with its roots in scientific inquiry, (c) needs to happen in community, in interaction with others, and (d) requires attitudes that value the personal and intellectual growth of oneself and of others.

Reflection supports preservice teachers to become self-aware. Developing selfawareness is an essential tool for teachers and is central to the development of reflective practice (Harrison, 2008). Lee (2005) points out that through awareness and understanding of themselves, preservice teachers can challenge and reinforce themselves and their teaching performance. Lee further adds that constant review and analysis will lead preservice teachers to be more reflective and better teachers. It is also highlighted that reflection is a response to past experience and involves conscious recall and examination of the experience as a basis for evaluation and decision-making and as a source for planning and action (Mirzaei et al., 2014).

Given that reflection is a conscious process, it supports students to be active learners. Procee (2006) emphasizes that to engage in reflection on experiences, an individual's active participation is required. Moreover, reflection encourages students to learn cooperatively. Leijen et at. (2012) argue that reflection needs to happen in community in interaction with others. They add that the focus of reflection can vary from a concrete technical aspect of an experience to the broader societal context of that experience, and the quality of reflection can be described through four successive stages of argumentation: (1) describing, (2) 
justifying, (3) evaluating and (4) discussing. Leijen et al. (2014) points out that group reflection enables individuals to share and learn from experiences and ideas from others' perspectives, reinterpreting and developing their own perspectives further.

In addition to supporting active learning and cooperation, reflection fosters experiential learning (Reynolds, 2012). Thus, to be considered reflective, thinking must translate into action. According to Harrison (2008), experiential learning is an approach which attempts to explain the relationship between experience and learning. Accordingly, people learn from their experience through reflection on the things they do and experimentation in similar experiences at another time in order to gain further experience and then reflect again and the cycle continues.

According to Harrison (2008):

The notion of the reflective practitioner is an enticing one. It starts with messy, unpredictable practices, unpicks what is going on, generates inductive hypotheses, asks for analysis and attempts to reveal more about the nature of expertise with the professional setting and the judgments upon that. It provides an important counterbalance to current emphases in policy making on evidence-based practice, in which certainty and technical rationality are the ideals (p.40).

Rieger et al. (2013) highlight the need for prospective teachers to be reflective early on in their career to be able to link theoretical concepts to practice, construct their own teaching philosophy, and acquire generic skills such as decision making. They state: 
Preservice teachers should engage in activities promoting reflection and reflective thinking early on in their teacher education preparation programs so that they can make sense of the studied theoretical content during their coursework. Incorporating reflection early in the program allows preservice teachers the opportunity to consider how newly acquired theories shape their understanding of their own teaching philosophy. Such reflective thinking will, in turn, help them become more effective decision makers about their own teaching practice as they make the transition to becoming a reflective inservice teacher (p.185).

Relying on Moffett's "I, You, and It" theory (cited in Rieger et al., 2013), the speaker-audience (I-You) and the speaker-subject (I-It) continua shed light on the several skills involved in reflective practice. The I-You relationship includes four stages: inner vocalization, outer vocalization, informal writing, and publication. Publication, in this sense, means making the reflection public, such as when sharing and interacting with others in discussion forums, logs, and focus groups. The I-It relationship focuses on four levels of abstraction: recording an experience, reporting an experience, generalizing from an experience, and theorizing from an experience. This relationship takes into consideration preservice teachers first developing an awareness while teaching-recording an experience and moving along levels of abstraction as reflections become deeper and substantive. Generalizing and theorizing from an experience requires taking action, evaluating results, and considering future instructional decisions.

Harrison (2008) suggests a model of reflective thinking consisting of five core competences to be necessary for good practice as a reflective practitioner. These five competences are: observation, communication, team working, judgment, 
and decision making. Harrison (2008) notes that all these aspects 'are important professional competencies and are applicable to all stages of teacher learning, including initial teacher education' (p. 22). Harrison (2008) describes various ways in which teachers might develop the above-mentioned competences. The skill of observation (defined as noticing one's feelings and behaviors) might be developed through writing and video- and audio-recording. Communication skills, verbal and non-verbal, such as listening and speaking as well as written communication could also make use of the previous activity of video-viewing. Video-viewing enables student teachers to notice communication patterns and pay attention to verbal and non-verbal communication skills such as body language, eye contact, and tone of voice. Teachers will find themselves working in a number of teams from the start of their teaching career: their subject team, their pastoral team and cross-curricular groups working on particular issues such as personalized learning and aspects of assessment, and so on.

As for the skill of judgment, teachers might, rather skillfully, combine details of the event with their judgment, or with additional explanations and theories. As a judge, it is important to find the best idea and not wait for the perfect one. Student teachers can develop decision making skills through reflective writing assignment and writing analysis of a teaching case; two activities which have the potential to exert tremendous influence on their perceptions of teaching and learning.

The model of reflective thinking suggested by Harrison (2008) is adopted in the current study to measure EFL student teachers' reflective thinking. With its focus on observation, communication, team work, judgment and decision making, the model attends to various skills necessary for EFL prospective teachers not only to be self-aware of their practice, but also to engage actively in 
the reflection process through interaction and cooperation with others as well as develop higher order thinking skills such as judgment and decision making.

\section{PBL}

PBL is aligned with the constructivist framework that views learning and teaching as the active and meaningful inquiry and building of knowledge by learners (De Simone, 2008). Hmelo-Silver (2004) points out that PBL is well suited to helping students become active learners because it situates learning in real-world problems and makes students responsible for their learning.

Torp \& Sage (2002) define PBL as focused, experiential learning organized around the investigation and resolution of messy, real-world problems. They identified three main characteristics of PBL which are: (1) engaging students as stakeholders in a problem situation, (2) organizing curriculum around a given holistic problem, enabling student learning in relevant and connected ways, and (3) creating a learning environment in which teachers coach student thinking and guide student inquiry, facilitating deeper levels of understanding. HmeloSilver \& Barrows (2006) define the PBL process as referring to a small group process that features ill-structured problems, hypothesis generation, revision and evaluation, inquiry, decision-making, identification of learning issues, selfdirected study, and reflection.

In PBL, the role of the teacher becomes that of a facilitator. Hmelo-Silver (2004) points out that the PBL facilitator carries out two main roles (a) guiding the development of higher order thinking skills by encouraging students to justify their thinking and (b) externalizing self-reflection by directing appropriate questions to individuals. Hmelo-Silver (2004) further adds that the facilitator plays an important role in modeling the problem solving and skills 
needed for self-assessing one's reasoning and understanding and in helping students learn to collaborate well, so they are better able to construct flexible knowledge. According to Hmelo-Silver (2004), facilitators progressively fade their scaffolding as students become more experienced with PBL until finally the learners adopt many of the facilitators' roles.

The PBL process is a cycle involving various stages. Hmelo-Silver (2004) suggested a model of the PBL cycle as represented in Figure (1).

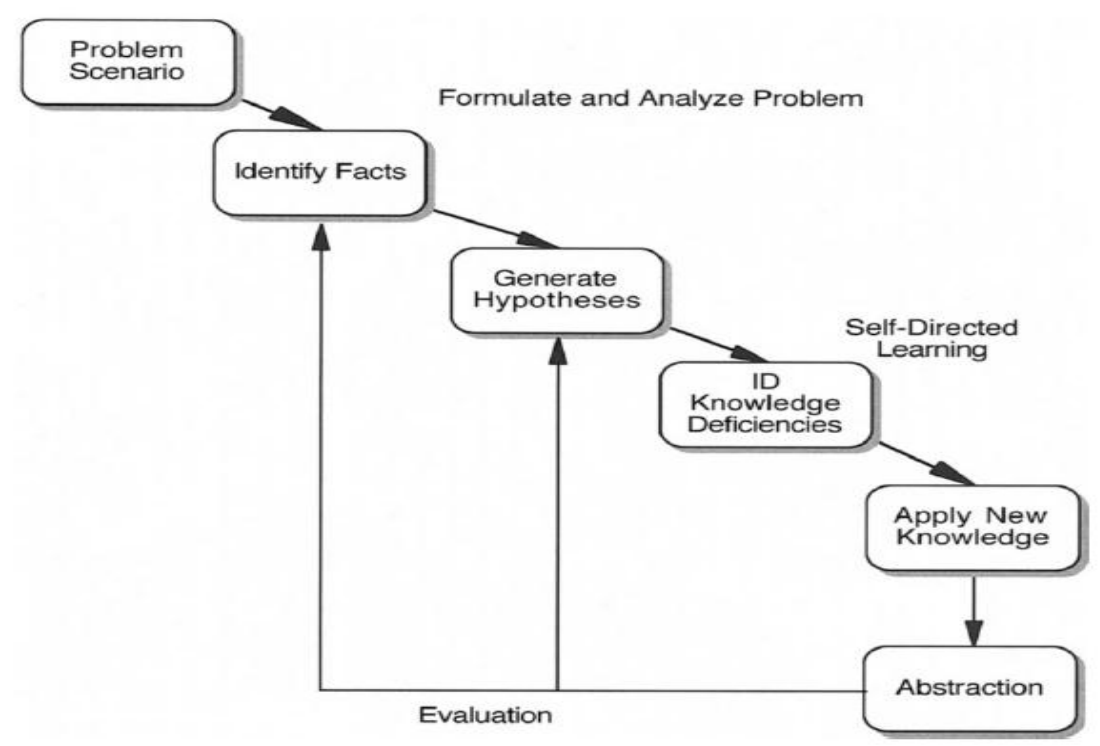

Figure (1) The PBL cycle (Hmelo-Silver, 2004, p.237)

According to Hmelo-Silver (2004), the students, in the PBL cycle illustrated in figure (1), are presented with a problem scenario. They formulate and analyze the problem by identifying the relevant facts from the scenario. As students understand the problem better, they generate hypotheses about possible solutions. An important part of this cycle is identifying knowledge deficiencies relative to the problem. These knowledge deficiencies become what are known as the learning issues that students research during their self-directed learning. Following self-directed learning, the students apply their new knowledge and 
evaluate their hypotheses in light of what they have learned. At the completion of each problem, students reflect on the abstract knowledge gained.

The PBL cycle was adopted in the current study while training EFL student teachers in a micro-teaching course. The steps were incorporated as part of the training given to the experimental group.

\section{Context of the study}

EFL student teachers in the current study lacked reflective teaching skills, which are an integral component of the professional practice of teachers. Based on the findings of a test of reflective thinking (see Appendix A) administered to both the experimental and control groups, the mean scores were as low as 10.93 and 13.06 out of 105 for the two groups consecutively. These findings highlight the problem of the study in that EFL student teachers in the current study lacked essential reflective thinking skills.

To tackle the-above described problem, the current study attempted to identify the effect of using PBL in a micro-teaching course on developing EFL student teachers' reflective thinking and attitudes towards the Micro-teaching course. Thus, the aim of the study was to answer the following two questions:

1- What is the effect of using PBL in a micro-teaching course on developing EFL student teachers' reflective thinking?

2- What is the effect of using PBL in a micro-teaching course on developing EFL student teachers' attitudes towards the course? 


\section{Hypotheses}

1- There will be a statistically-significant difference at the level of (0.05) between mean scores obtained from the experimental and control groups in the reflective thinking post-test favoring the experimental group.

2- There will be a statistically-significant difference at the level of (0.05) between mean scores obtained from the experimental and control groups in the post administration of the attitude scale favoring the experimental group.

\section{Method}

The canons of the quasi-experimental research design were followed in the current study. The experimental group was trained by the researcher in PBL in combination with a guided reflection procedure whereas the control group was trained by a colleague in the conventional method of student teachers giving mini-lessons followed by class discussion and commentary. To minimize carryover effects between the two conditions, the sections were scheduled on consecutive days of the week with the control class earlier and the experimental class later.

PBL and conventional instruction classes for both experimental and control conditions met 12 times during the course, for two hours a week. In the PBL class, the researcher gave mini-lectures on teaching skills and trained the students to analyze classroom problems in pairs and small groups. To probe their prior knowledge and experiences, mini-lectures were typically given after students had discussed their learning issues. In fact, their discussions often provided the content for these lectures. Pair work and small-group discussions 
allowed students to give each other feedback. The training also incorporated a guided reflection procedure and the PBL procedure that will be described in the training techniques section.

\section{Participants}

The study took advantage of two intact groups of prospective teachers who were randomly assigned into an experimental group and a control one (thirty students in each group). The researcher taught a micro-teaching course to the experimental group and a colleague at the same department taught the same course to the control group. The two groups were part of the cohort of second year EFL student teachers (Primary Education) at the Faculty of Education, Minia University. They took the course at the first term of the academic year $2017 / 2018$.

\section{Training material and techniques}

Both the experimental and control groups studied the micro-teaching course book which focused on providing students with basic teaching skills such as lesson planning, presentation, communication, classroom management, and assessment. There were chances for both groups to give micro-teaching sessions and receive feedback from classmates and instructors on their teaching as was the conventional teaching method of the course. However, for the experimental group, the student teachers were also trained in and practiced the steps and procedures of the PBL method which was integrated in the course. The use of PBL was preceded by students giving mini-lessons as micro-teaching sessions. These sessions were video-recorded, then viewed and reflected upon in class and in writing through a guided reflection procedure. As a result, common problems 
were identified and constituted the cases for PBL. Thus, the training consisted of two phases. The first phase represented the guided reflection procedure and the second phase represented the PBL procedure. These two phases are explained below.

\section{The guided reflection procedure}

The guided reflection procedure was an integral part of the course. Rieger et al. (2013) argue that the best way of encouraging reflection is to provide preservice teachers with relevant strategies and activities that require them to use reflection and reflective thinking skills.

The guided reflection procedure was adapted from Husu et al. (2008) who used it in an initial teacher education program. The goal of this procedure was to foster the student teachers' ability to reflect on teaching and to construct professional agency and acquire such knowledge and skills they need when they enter into the teacher profession. The procedure emphasized the student teacher's personal aims and goals of learning, interaction with others, spoken and written reflection, and time used for prolonged reflection. The guided reflection procedure (as applied in the current study) consisted of three stages. The first stage was about initial reflection. A part of a lesson taught by student teachers and lasted for 5 to 10 minutes was video-recorded. Video-recording is one of the practices that have been suggested in the literature to teach reflection and encourage reflective thinking skills (Romano \& Schwartz 2005; Halter 2006; and Welsch \& Devlin 2007; and Rieger, 2013). For instance, Rieger (2013) points out that video recording is useful at both personal and collaborative levels as it provides preservice teachers with the opportunity to 
reflect on personal teaching practices and to engage in conversation with others concerning peer and personal teaching performances.

Immediately after the recoding, the student teachers' initial comments and remarks were discussed. The student teachers were asked to mention at least one positive remark about the student teacher's performance and one behavior or skill that needed to be improved. The second stage was about oral reflection that took place a week after the video-taping of the student teachers' mini lessons. The whole group viewed the recorded video and worked in pairs to give detailed comments and remarks about the recorded lessons. Handouts of an observation sheet (See appendix C) were given to the student teachers to use as reference points and triggers for constructing feedback. Follow-up discussion was carried out to extract useful lessons from the experience and for the instructor to link experience to relevant concepts and theories. The third stage was about written reflection and took place as an assignment to be submitted one to two weeks after the oral reflection. During this phase, student teachers reflected on the performances in an individual writing assignment. The student teachers who taught the mini-lessons were asked to describe their feelings and the lessons they learned from the experience. The rest of the students were asked to write a report about each student teacher addressed as a letter to the student teacher concerned. The content of the letter was intended to be about the student teacher's strong and weak points followed by pieces of advice on how to improve and any other concluding remarks. 


\section{The PBL procedure}

Based on the guided reflection procedure described above, certain problems were common and repeated in student teaching. Three stood out as the most prominent ones and represented three cases for problem solving. The first one was related to classroom management skills and actions to help a beginning teacher who was not able to manage the classroom well. The second case was concerned with methods and activities to help a teacher increase student talking time and use CLT (Communicative Language Teaching) instead of GTM (Grammar Translation Method). The third case was about communication skills and ideas to help a struggling teacher who lacked communication skills. These problem cases were presented to the student teachers who were divided into groups to tackle these problems. The researcher designed the cases in light of the two conditions set for problem cases by De Simone (2008). These two conditions are: (1) the cases used in PBL should be authentic, relevant and illdefined (i.e., there are numerous ways of approaching the problem as well as diverse responses), and (2) they must also require the problem solver to draw upon multiple sources and perspectives. The cases also required the participants to think beyond the information presented and to draw from multiple sources of information to work through the problem. The cases were also well-suited to the topics discussed in the course.

The PBL procedure consisted of six stages as follows:

\section{Stage 1: Group setting}

The student teachers worked in small groups. The group consisted of 5 to 7 students. One of the students led the group (Group Leader) and worked as a coordinator to submit the group report. Within each group, the students 
cooperated in discussion, writing notes of what was said and discussed. The instructor (the tutor, as known in PBL) monitored the process and stayed at the background to provide a safe learning environment.

\section{Stage 2: Problem identification}

Three problems (in the form of cases) from the students' micro-teaching practice were described and given as a handout to the groups. Each group chose one problem to work on. Students read through the problem, then identified and clarified any concepts they did not understand. Through brainstorming, students discussed the problem to generate ideas about it. At this stage, there was no sifting of ideas. Students tried to get a picture of the puzzle and its individual pieces based on prior knowledge. Thus, students got a good idea of the structure of the problem and identified what they needed to find out about it.

\section{Stage 3: Formulating learning goals}

Based on what they needed to find out, students (with the help of the tutor) formulated learning goals in the form of concrete questions that represented the learning issues they needed to find information about.

\section{Stage 4: Self-study}

Self-study is the research stage or independent study stage after deciding on the problem and learning issues to be tackled. The student teachers gathered information to answer the questions identified as learning goals in the previous stage, and prepared to share their findings with the rest of the group. 


\section{Stage 5: Reporting}

After self-study for two weeks, the group met again and shared their findings. They also discussed the findings with the tutor and the other groups.

\section{Stages 6: Consensus}

Based on what was presented, the groups tried (with the guidance of the tutor) to arrive at the best answers to the concrete questions. The tutor helped students reach consensus and ensured that the learning goals have been achieved. Some groups needed an additional week to do more research and resubmitted their work after modifying or supplementing it with additional findings.

\section{Learning resources in the PBL classroom}

Learning resources play an essential role in the PBL classroom because students spend a lot of time in research and independent study. Good use of learning resources enables the PBL learners to successfully complete the self-directed learning phases of the PBL cycle. It was essential for students to visit the library and e-learning resources such as the internet to collect information while working on the problem. In addition, the use of the white board proved to be useful in the PBL classroom. Hmelo-Silver (2004) suggests that the whiteboard is one valuable learning resource in the PBL classroom when used in the format shown in figure (2). 
Figure (2): The whiteboard in the PBL classroom

\begin{tabular}{|l|l|l|l|}
\hline Facts & Ideas & $\begin{array}{c}\text { Learning } \\
\text { issues }\end{array}$ & Action plan \\
\hline & & & \\
& & & \\
\hline
\end{tabular}

Adapted from Hmelo-Silver (2004)

While working through the problem, students use whiteboards to record their evolving ideas. The whiteboard is divided into four record-keeping columns to facilitate problem solving. The Facts column holds information that the students gleaned from the problem statement such as what the problem is and where it occurred. The Ideas column serves to keep track of their evolving hypotheses about solutions. The students place their questions for further study into the Learning Issues column. They use the Action Plan column to keep track of plans for resolving the problem or obtaining additional information. The whiteboard serves as a focus for negotiation of the problem and as a forum for students to co-construct knowledge. It helps students externalize their problem solving and allows them to focus on more difficult aspects of the problem-solving process. The PBL whiteboard provides a model of a systematic approach to problem solving and supports student planning and monitoring as they identify what needs to be recorded on or later removed from the board. 


\section{Instruments}

Two instruments were used to collect data of the study. They were designed by the researcher. The two instruments were a reflective thinking test and an attitude scale. They are described in the following sections.

\section{The reflective thinking test}

The aim of the reflective thinking test was to measure the effect of training the experimental group using PBL and to ensure the equality of the experimental and control groups before starting the training course. The test consisted of 35 questions with 3 marks for each question with a total score of 105 marks (see Appendix A). The test was in five parts (observation, communication, team work, judgment and decision making) based on the five reflective thinking core competencies suggested by Harrison (2008). To check the validity of the reflective thinking test, it was emailed to a panel of TESOL experts interested in language teaching and assessment whom the researcher met during the ILACE (International Language Assessment Conference in Egypt) held by the American university in Cairo in 2017. The experts were presenters at the conference and were asked for their feedback on the goals and content of the test. Three experts responded and provided their feedback. The test was modified accordingly.

Inter-rater reliability was used while marking the students' responses to the reflective thinking test. The participants' responses were rated on a scale of 0 to 3. A rubric for scoring the test answers was used by the researcher and another colleague to mark the answers. Given that most of the questions required that student teachers compose ideas related to the point in question, a system of marking was followed. The student teachers got three marks out of three when 
they gave three good ideas or two very good ideas or one excellent idea. They got two marks when they gave two ideas or one mark when giving one idea given that the ideas were not repeated to answer a previous question. A zero score was given when there was no answer or when the answer was irrelevant. Inter-rater reliability yielded $96 \%$ agreement on the test scores. The mean score of the two raters was calculated by adding up the two scores in the test and dividing the sum by two.

\section{The attitude scale}

The attitude scale towards the micro-teaching course (See appendix B) was designed by the researcher and consisted of twenty items to measure the student teachers attitudes towards the course. Two negative items were included in the scale to ensure that the participants read the statements and did not respond blindly. While completing the scale, the participants were instructed to choose one of four responses (ranging from strongly agree to strongly disagree) to each item according to their point of view. The responses were analyzed according to the values they were given during data input: strongly agree ( 4 points), agree ( 3 points), disagree ( 2 points), and strongly disagree (1 point). The values of the negative items were reverted during the data entry. The reliability analysis of the scale was checked using SPSS (Statistical package for Social Sciences) and revealed that the value of Cronbach's Alpha was (.856) for the overall scale.

\section{Results}

SPSS analysis of the reflective thinking post-test scores revealed a statistically significant difference at the level of (0.05) favoring the experimental group. Therefore, the first hypothesis is accepted and training proved to be effective in 
developing the experimental group's reflective thinking. Table (1) presents the ttest results of the reflective thinking post-test.

Table (1): The t-test results of the two groups in the reflective thinking preand post-tests

\begin{tabular}{|l|c|c|c|c|c|c|c|}
\hline & Group & N & Mean & SD & t-value & Df & $\begin{array}{c}\text { Sig. } \\
\text { (2-tailed) }\end{array}$ \\
\hline \multirow{2}{*}{ Pre-test } & Experimental & 30 & 10.93 & 7.38 & .906 & 58 & .369 \\
\cline { 2 - 5 } & Control & 30 & 13.06 & 10.57 & & 58 & \\
\hline \multirow{2}{*}{ Post-test } & Experimental & 30 & 42.20 & 11.01 & 10.636 & 58 & .000 \\
\cline { 2 - 5 } \cline { 5 - 6 } & Control & 30 & 14.86 & 8.76 & & 58 & \\
\hline
\end{tabular}

It is worth noting that the mean score of the experimental group has risen from (10.93) in the pre-test to (42.20) in the post-test whereas the mean score of the control group has risen from (13.06) in the pre-test to (14.86) in the post-test.

Item response analysis of the reflective thinking post-test for the experimental group (see Table 2) was carried out to identify the most-developed areas of reflective thinking. The means of the items were compared and ranked according to their values. Thus, the items were rearranged in a descending order with items at the top (with the higher means) representing the most-developed areas. The item response analysis revealed that the experimental group developed in the five domains of reflective thinking: observation, communication, teamwork, judgment and decision making. Evidently, the student teachers (1) became aware of the value and application of videorecording, (2) became aware of the definition, components, value and 
application of a lesson observation sheet, (3) became aware of the definition, types, criteria, skills, application and value of teacher assessment, (4) were able to reflect on their strengths and weaknesses as prospective EFL primary school teachers, (5) became aware of the elements and skills of communication in English Language Teaching (ELT), (6) became aware of the value and application of team work skills in ELT, (7) were able to analyze and evaluate a problematic case scenario related to ELT, and (8) were able to choose and justify an appropriate course of action related to various aspects of ELT.

\section{Table (2): Item response analysis of the reflective thinking post-test of the experimental group}

\begin{tabular}{|c|c|c|c|c|c|c|}
\hline No. & Areas of development & Domain & Min. & Max. & Mean & $\begin{array}{l}\text { Std. } \\
\text { Deviation }\end{array}$ \\
\hline 1 & Providing advice to a struggling teacher & Judgment & .00 & 3.00 & 2.3333 & .84418 \\
\hline 2 & Awareness of communicative skills & Communication & .00 & 3.00 & 2.0000 & 1.20344 \\
\hline 3 & $\begin{array}{l}\text { Choosing the right course of action to prevent } \\
\text { cheating }\end{array}$ & Decision making & 1.00 & 3.00 & 1.7333 & .73968 \\
\hline 4 & Taking the role of the teacher & Judgment & .00 & 3.00 & 1.7333 & .86834 \\
\hline 5 & Analyzing a teacher's difficult situation & Judgment & .00 & 3.00 & 1.7333 & 69149 \\
\hline 6 & Awareness of good communication skills & Communication & .00 & 3.00 & 1.7333 & .78492 \\
\hline 7 & $\begin{array}{l}\text { Choosing a right course of action to establish } \\
\text { classroom management rules }\end{array}$ & Decision-making & .00 & 3.00 & 1.7000 & .83666 \\
\hline 8 & Justifying a student's behavior & Judgment & .00 & 3.00 & 1.6333 & .85029 \\
\hline 9 & Analyzing students' misbehavior & Judgment & .00 & 3.00 & 1.6333 & .61495 \\
\hline 10 & $\begin{array}{l}\text { Choosing the right course of action related to } \\
\text { the use of praise }\end{array}$ & Decision-making & .00 & 3.00 & 1.5667 & .77385 \\
\hline 11 & Analyzing a teacher's reaction & Judgment & .00 & 3.00 & 1.3667 & .71840 \\
\hline 12 & Awareness of body language & Communication & .00 & 3.00 & 1.3667 & .92786 \\
\hline 13 & Awareness of eye contact & Communication & .00 & 2.00 & 1.3333 & .71116 \\
\hline 14 & Explaining the value of video-recording & Observation & .00 & 3.00 & 1.2667 & .86834 \\
\hline 15 & $\begin{array}{l}\text { Listing the benefits of team work in lesson } \\
\text { planning }\end{array}$ & Teamwork & .00 & 2.00 & 1.2667 & .86834 \\
\hline
\end{tabular}




\begin{tabular}{|c|c|c|c|c|c|c|}
\hline No. & Areas of development & Domain & Min. & Max. & Mean & $\begin{array}{l}\text { Std. } \\
\text { Deviation }\end{array}$ \\
\hline 16 & $\begin{array}{l}\text { Explaining how assessment can improve } \\
\text { teaching }\end{array}$ & Observation & .00 & 3.00 & 1.2333 & 1.19434 \\
\hline 17 & Awareness of effective communication & Communication & .00 & 2.00 & 1.2000 & .66436 \\
\hline 18 & Awareness of teaching assessment & Observation & .00 & 3.00 & 1.2000 & .96132 \\
\hline 19 & Awareness of criteria of teacher assessment & Observation & .00 & 3.00 & 1.1667 & 1.11675 \\
\hline 20 & Awareness of CLT & Communication & .00 & 2.00 & 1.1667 & .79148 \\
\hline 21 & Awareness of types of assessment & Observation & .00 & 3.00 & 1.1333 & .97320 \\
\hline 22 & Awareness of tone of voice & Communication & .00 & 2.00 & 1.1000 & .66176 \\
\hline 23 & Listing the benefits of team work & Teamwork & .00 & 3.00 & 1.0667 & .78492 \\
\hline 24 & Awareness of the application of team work & Teamwork & .00 & 3.00 & 1.0667 & 1.01483 \\
\hline 25 & $\begin{array}{l}\text { Awareness of perceived strengths and } \\
\text { weaknesses }\end{array}$ & Observation & .00 & 3.00 & 1.0667 & .98027 \\
\hline 26 & Listing the benefits of video recording & Observation & .00 & 2.00 & 1.0333 & .80872 \\
\hline 27 & Defining an observation sheet & Observation & .00 & 2.00 & 1.0333 & .61495 \\
\hline 28 & Awareness of the value of feedback & Communication & .00 & 3.00 & .9667 & .80872 \\
\hline 29 & Listing the benefits of observation & Observation & .00 & 3.00 & .9667 & .88992 \\
\hline 30 & $\begin{array}{l}\text { Listing the benefits of team work in co- } \\
\text { teaching }\end{array}$ & Teamwork & .00 & 3.00 & .9333 & .90719 \\
\hline 31 & $\begin{array}{l}\text { Listing the benefits of benefits of team work in } \\
\text { lesson evaluation }\end{array}$ & Teamwork & .00 & 3.00 & .8667 & .97320 \\
\hline 32 & Awareness of the uses of assessment & Observation & .00 & 2.00 & .7667 & .85836 \\
\hline 33 & Pointing out the value of an observation sheet & Observation & .00 & 2.00 & .7667 & .72793 \\
\hline 34 & Awareness of the characteristics of pupils & Communication & .00 & 2.00 & .6667 & .75810 \\
\hline 35 & Awareness of teaching assessment skills & Observation & .00 & 3.00 & .6667 & .88409 \\
\hline
\end{tabular}

It is evident from table (2) above that two particular domains of reflective thinking came on top as the most-developed areas. These two domains were judgment and decision-making. This finding indicates that PBL is an effective approach to develop student teachers' reflective thinking skills in general, and judgment and decision-making in particular. 
To elaborate on the previous finding, analysis of the test items in terms of Bloom's taxonomy of cognitive levels was carried out to classify the items as either pertinent to Lower Order Thinking Skills (LOTS) or Higher Order Thinking Skills (HOTS). Interestingly, all the items representing judgment and decision making in the reflective thinking test were classified as HOTS representing the three top levels of Bloom's taxonomy: application, synthesis and evaluation. Therefore, another finding was revealed that PBL in the current study developed the student teachers' HOTS as represented by judgment and decision-making.

As for the second hypothesis, the analysis of the attitude scale revealed no significant differences between the mean scores of the experimental and control groups in their attitudes towards the course. Therefore, the second hypothesis is rejected. Table (3) presents the findings of the attitude scale.

Table (3): The t-test results of the attitude scale of the two groups in the post-test

\begin{tabular}{|c|c|c|c|c|c|c|c|}
\hline & Group & N & Mean & SD & t-value & Df & $\begin{array}{c}\text { Sig. } \\
\text { (2-tailed) }\end{array}$ \\
\cline { 1 - 7 } Post-test & Experimental & 30 & 68.03 & 5.33 & .430 & 58 & .669 \\
\cline { 2 - 5 } & Control & 30 & 67.33 & 7.13 & & 58 & \\
\hline
\end{tabular}

Although no significant differences were found between means of scores of the experimental and control groups in the post-test of the attitude scale, their mean scores were high. The mean score of the experimental group was (68.03) whereas that of the control group was (67.33) with $85.03 \%$ and $84.16 \%$ levels 
of agreement of both groups consecutively to the scale items. In other words, both groups had positive attitudes towards the course.

The positive attitude of the experimental group may be attributed to increased motivation as a result of the PBL intervention. As for the control group, the positive attitude towards the Micro-teaching course may be attributed to the student teachers' increased motivation as a result of the instructor's style, the perceived importance of the course by the student teachers, and/or the small class size of the course compared to the large class size in general lectures.

\section{Discussion}

Two major findings were revealed in the current study. The first finding was that using PBL proved to be effective in developing the student teachers' reflective thinking in general and the two areas of judgment and decision making in particular. This finding is in agreement with previous literature (e.g. Mirzaei, 2014; Rieger et al., 2013; Harrison, 2008; and Hmelo-Silver \& Barrow, 2006).

Qualitative analysis of the responses of participants of the experimental group in the reflective thinking post-test revealed that they developed reflective thinking in the five areas of observation, communication, team work, judgment, and decision making. Some quotes from these participants will be presented here under each one of the five areas of the reflective thinking test.

As for observation, below are some quotes from the participants:

Video-recording facilitates evaluating student interaction and teacher performance by giving and receiving feedback. It is also very effective in self-evaluation (participant 25). 
Video recording helps me remember a lot of details because I learn best when I see actions (participant 3).

Observation is useful to know whether the pupils understand or not. If I find that a lot of the pupils do not understand, I will improve my method of teaching (participant 3).

A lesson observation sheet is an important tool for the teacher to know how and what to observe (participant 21).

Teaching assessment helps the teacher document the learning process (participant 24).

Teacher assessment is necessary to pay attention to my mistakes and avoid repeating them (participant 4 ).

Assessment helps me to know more about my students (participant 14).

My strong points as a teacher are my ability to control the class and my way of dealing with the pupils in a friendly way, but my weak point is lack of confidence in myself (participant 6).

My greatest weakness is that I don't like using punishment even if it is necessary. My greatest strength is that I could make my teaching interactive through good communication and through elicitation (participant 25).

It is evident from the previous quotes that the participants highlighted the role of video-recording in evaluating self and others (participant 25). It is suggested that the use of video recording attends to different learning style preferences and therefore appeals to a large number of learners (participant 3). The role of observation to follow up students' learning and guide the student teacher's 
personal development and growth was also highlighted (participant 3). The lesson observation sheet raised the teacher's awareness with regard to the way and criteria of observation (participant 21). In addition, documentation is seen as an aspect of quality teaching (participant 24). Besides, the role of assessment in the student teacher's self-improvement is highlighted (participant 4). It is also asserted that knowledge of students is gained from assessment results (participant 14). In addition, teacher self-assessment is part of the student teachers' reflective comments when they reflected on their strengths and weaknesses (participants $6 \& 25$ ).

The participants' responses to the section on communication in the reflective thinking test also revealed evidence of them developing reflection. Below are some quotes from the participants:

Primary school pupils are positive and creative (participant 5).

The teacher communicates well when she gives feedback to the pupils, ask them clear and specific questions, and encourage them to answer (participant 2).

Eye contact keeps the pupils attentive (participant 29).

Eye contact makes the pupils feel that the teacher cares about them (participant 8).

Eye contact helps the teacher observe pupils (participant 20).

The use of body language is a sign that the teacher is active and interested while presenting the lesson (participant 6).

Using gestures and facial expressions such as 'thump up' and 'smiling' makes teaching more interesting and effective (participant 15). 
The teacher's body language help pupils focus attention and consequently lead to better communication (participant 17).

When the teacher uses body language, she becomes like an actor (participant 23).

Body language is a powerful tool in miming some new vocabulary (participant 25).

Varying the tone of voice helps students remember the lesson for a long time (participant 17).

Feedback helps the pupils understand how well they are making progress toward learning goals (participant 29).

It is highlighted from the participants' quotes in the communication section that pupils at an early age are seen as active and creative (participant 5). It also highlighted that feedback, clarity of language, questions and answers exchanges were among necessary communicative skills for teachers (participant 2). Moreover, paying attention is seen as facilitating successful communication (participant 29). In addition, eye contact helps the teacher establish rapport with the pupils (participant 8). It also has a monitoring function for the teacher and suggests a new role for the teacher as observer (participant 20). Body language, as a communicative skill, is regarded as the silent language of successful teachers (participants $6 \& 15$ ). Teaching by acting is also supported (participant 23). The role of body language in teaching EFL is underscored (participant 25). In addition, the role of the tone of voice in learning retention was also emphasized (participant 17). It is also underlined that the provision of feedback monitors the achievement of learning goals (participant 29). 
Team work was developed as a third area of reflective thinking as shown by the participants' quotes below:

Team work helps the teacher do her best and feel relaxed (participant $30)$.

Team work increases student talking time in class (participant 11).

Team work taught me how to accept others' ideas even if they didn't agree with mine (participant 19).

When we worked as a team, each one of us had a particular job to focus on, so we managed to finish the assignment in a short time (participant 16).

If we use co-teaching, every teacher will benefit from the teaching style of the other teacher. Besides, no one is perfect, and when we teach in this way, we complement one another. This also will be beneficial for the pupils (participant 3 ).

Team work improved my self-confidence (participant 6).

I learned from team work the value of sharing my opinion with others. I also learned from it how to be a leader (participant 6).

Team work helped me to improve my language skills and to learn about communication skills (participant 7).

According to the previous quotes, it is highlighted that team work provides a safe and productive learning environment for the learners (participant 30). Team work has also a positive influence on student-student interaction and encourages communication (participant 11). It helps the participants develop communication and tolerance of others' different ideas (participant 19). The 
quotes also highlight that distributing work in a team saves time while completing a task (participant 16). The role of co-teaching in promoting team work skills is highlighted (participant 3). Team work also helps student teachers to acquire generic personal skills such as leadership (participant 6). The same participant reported having a lack of self-confidence. Being a leader needs a lot of confidence. Thus, team work helped a lot in enhancing the lack of the teacher's lack of confidence. Moreover, language and communication skills were reported as gains from team work (participant 7).

The participants developed judgment as a fourth component of reflective thinking. Evidence for this in shown in their quotes below in response to the section of judgment in the reflective thinking test (see appendix A):

The teacher is neither patient enough not experienced to deal with the difficult situation. He is also irresponsible. He doesn't have the main responsibility of a teacher, i.e. 'response ability' (participant 25).

The pupils were not ready to learn (participant 6).

The pupils were hooligans (participant 12).

The pupils were not willing to participate (participant 29).

The pupils needed a confident, creative and friendly teacher to get them on his side (participant 15).

The pupils wanted to discover the teacher's character (participant 25).

One reason could be that the pupils don't like the subject from a previous experience of a bad teacher (participant 26).

The teacher should have warned them first (participant 29). 
The teacher didn't make use of his authority and punish the pupils for their misbehavior (participant 1).

The teacher left them without punishment. Therefore, they were not reminded that what they did was not respectful (participant 9).

The teacher should be firm with misbehaving pupils (participant 20).

The teacher should set rules for expected behaviors in class. The teacher should also make the pupils busy all the time (participant 23).

The teacher should have controlled himself and the class. He also should have used suitable teaching methods and techniques. For example, he should have varied his tone of voice to attract the pupils' attention (participant 6).

The teacher should have taken it as a joke, but also establish a rule that this would not be permitted again in class (participant 18).

The teacher should be a leader (participant 12).

The teacher should have made three important steps to tackle the problem. First, he should have asked about who made the misbehavior and warn him against repeating the act again. Second, he should have put some rules to control the class well. Third, he should have made the students practice the lesson and use elicitation and interactive activities to draw the pupils' attention and keep them on task (participant 25).

The quotes above highlight that the teacher's response to the situation was unsatisfactory as he was described as indifferent and lacked essential teacher qualities to tackle difficult situations such as the one described (participant 25). Participant 6 highlighted the need to learn about the pupils 'state of mind' and to 
respond to the pupils' needs. It is asserted that the pupils bullied the teacher and therefore they should bear the consequences of their harassment act (participant 12). It was also reported that the pupils lacked willingness to communicate (participant 29). However, it is asserted that gaining the pupils' empathy and trust needs the teacher to have certain characteristics (participant 15). Pupils like to explore as this is part of their nature (participant 25). Other quotes suggest that the teacher has authority as well as the right to protect himself from misconduct (participant 1). It is also highlighted that pupils need to be reminded of expected behaviors to stop misconducts and to have a code of ethical behavior instilled in them (participant 9). Some suggestions included setting rules for practice and maximizing time on-task (participant 23). The participants were able to pinpoint problematic teacher actions and suggest alternative course of action to deal with the pupils' misbehavior (e.g. participant 6). It is also highlighted that primary school teachers need to remember that they deal with kids whose part of their nature is play (participant 18). The teacher should be a leader; otherwise, the pupils could take the class to an unfavorable direction (participant 12). One of the student teachers suggested a formula for dealing with the problem (participant 25).

The last area of reflective thinking developed was decision making as could be inferred from the two quotes below:

This is because reacting in a positive way is one of the best techniques to get pupils to behave well (participant 15).

This is because one of the important principles of classroom management is establishing rules (participant 16). 
The participants were able to choose a particular course of action and justify their choices as evident from the quotes above. Participant 15 suggests that being positive facilitates classroom management and modifies pupils' misbehavior. In addition, the need to set rules for class behavior is highlighted when the teacher reminds everyone in class that side talk is not allowed during the lesson (participant 16).

Another finding of the study was related to the effect of PBL on the attitudes of student teachers. Both experimental and control groups had positive attitudes towards the Micro-teaching course at the end of the training course. This implies that PBL was not the direct reason for effect on the attitudes of the experimental group, and their positive attitudes could be attributed to other reasons. However, this may not be the case because the issue of changing the students' attitudes in PBL is not a straightforward matter. This remark is pointed out in previous literature.

Hmelo-Silver (2004) revealed that, in studies other than medicine where most courses follow PBL format, the instructional intervention was a single experimental course within a larger curriculum with competing demands from other well-structured courses. A single course may not provide the opportunity to become acclimated to a new way of learning. This makes attitudes in PBL a complex issue. It also implies the PBL may not be rejected as a potential reason for the experimental group positive attitudes. Previous literature resonates with this argument. Hmelo-Silver (2004) highlights three features of PBL that support increased motivation for learning. Accordingly, PBL students are more motivated (a) when they value what they are learning, (b) when their educational activity is implicated in personally meaningful tasks, and (c) when they believe 
that the outcome of learning is under their control. It is also argued that PBL instruction techniques assume that two goals related to increasing students' intrinsic motivation are achieved as part of the PBL learning cycle (HmeloSilver, 2004). First, problems provide students with the proximal and tangible goal of applying their knowledge to solve a concrete problem. Second, classroom contexts that reward students for deep understanding, independent thought, and action are more motivating than many traditional classroom structures that reward comparative performances. Hmelo-Silver (2004) further adds that the problem in PBL can play an important role in increasing students' intrinsic motivation as long as it is realistic and resonates with their experiences.

Based on the findings of the current study, three important remarks need to be highlighted. The first remark is that video-viewing, as used in the training procedures in the current study, is a powerful tool to facilitate reflection. This is in line with existing literature. For instance, Leijen et al. (2014) found that video viewing helped students to observe the recorded lesson as a bystander. It enabled them to notice details about themselves or pupils that they would not have noticed otherwise. These details included the sound of their voice, body language, and vocabulary. The students also reported that their initial feelings in the course of teaching the lesson were often more insecure and negative in comparison to their feelings after having viewed the lessons on video. Therefore, seeing oneself on video seemed to give them assurance that the lesson did not go as bad as the first-hand emotions suggested. Observations made on the bases of the video helped them during the next lessons. They explained that they were more aware of the aspects seen on video and tried to avoid the same mistakes. 
The second remark to be highlighted is that PBL supports student teachers to learn collaboratively as evident by the findings of the current study. De Simone (2008) highlights that the probing that occurs between peers and expert facilitators in PBL enables prospective teachers to view the case from different and deeper perspectives. In the same vein, reflection is most beneficial when done collaboratively. When students work in groups, as is the case in PBL, team work and cooperation facilitates reflection and help students make use of group dynamics. This point was also highlighted by Leijen et al. (2014) who found that oral reflection conducted with a supervisor or a peer was more beneficial than reflecting alone and recommended that reflection should happen in interaction with others. Furthermore, Marcos et al. (2011) found that student teachers needed to be guided in order to reach a more profound analysis of their practice and further development of their own perspective. It is also highlighted that, in PBL, effective collaboration can lead to knowledge construction as students construct joint explanations through reflection and through the interdependence of learning within the group (Hmelo-Silver, 2004).

The third remark is that PBL bridges the gap between theory and practice. This was evident in the current study when the student teachers worked on the problem cases, reflected on their experiences and collected evidence related to the learning issues. As highlighted by Bereiter and Scardamalia (2006), PBL prepares teachers to construct a principled understanding of the issues in the problem case, so they learn to apply principles flexibly to problems of varying complexity. In the same vein, De Simone (2008, pp.187-188) states:

Professionals such as teachers face a particular struggle in eliminating the divide between practice and theory. Problem-based learning, with its emphasis on both scholarship and teaching practice, can accomplish this 
goal. In problem-based learning, the synergy between theory and practice fosters prospective teachers' problem solving, especially their ability to define the problem, generate solutions, and use both practical and literature-based resources to support the solution.

\section{Recommendations and suggestions}

The findings of the current study revealed the effect of using PBL in developing EFL student teachers' reflective thinking. Various groups could benefit from the current study. These groups include: curriculum designers, teacher educators, as well as student and practicing teachers. The various activities which constitute the training material in the study could be used by curriculum designers whose interest is in the area of PBL, reflective thinking and micro-teaching. Teacher educators in the field of teaching EFL may use the current training material and the suggested procedures followed while teaching the Micro-teaching course in their practice. In addition, both student and practicing teachers may find various pathways of teacher training and professional development based on the training techniques and procedures used in the current study.

Based on the findings of the study, some recommendations and suggestions can be made. Teacher education programs should focus, in training courses and workshops, on supporting student teachers to become reflective thinkers and link theory to practice through experiential learning approaches such as PBL. Holloway \& Gouthro (2011, p.31) recommend that reflective practice should begin in teacher education programs. They further state that 'Developing the capacity for critical thinking and reflection involves time and patience, as well as diligent efforts to engage with abstract theoretical writing that many learners find difficult.' 
The PBL model could be a suggested alternative for designing teacher education curricula. Two barriers to using PBL in education are the constraints of classroom organization in terms of teaching courses separately and the lack of a sufficient number of skilled facilitators (Hmelo-Silver, 2004). The model of PBL should involve an integrated, interdisciplinary curriculum organized around problems rather than subject domains. In addition, teacher education programs should equip prospective teachers with the needed skills to run a PBL classroom by introducing courses that encourage student teachers to reflect and solve problems. Further research in PBL could focus on its effect on higher order levels of thinking such as analytical, critical and creative thinking.

\section{References}

Benammar, K. (2004). Conscious action through conscious thinking: Reflection tools in experiential learning. Public seminar. Amsterdam: Amsterdam University Press.

Bereiter, C., \& Scardamalia, M. (2006). Education for the knowledge age: Design-centered models of teaching and instruction. In P. Alexander and P. Winne (Eds.), Handbook of educational psychology, (pp. 695-713). 2nd ed. Mahwah, NJ: Lawrence Erlbaum.

De Simone, C. (2008). Problem-Based Learning: a framework for prospective teachers' pedagogical problem solving. Teacher Development: An international journal of teachers' professional development, 12(3), 179-191.

Gungor, M. N. (2016). Turkish pre-service teachers' reflective practices in teaching English to young learners. Australian Journal of Teacher Education, 41(2), 137-151.

Halter, C. P. (2006). The reflective lens: The effects of video analysis on preservice teacher development (Doctoral dissertation). University of California, San Diego. 
Harrison, J. (2008). Professional development and the reflective practitioner. In S. Dymoke \& J. Harrison (Eds.), Reflective teaching and learning (pp. 7-45). London: Sage Publications.

Hmelo-Silver, C.E. (2004). Problem-based learning: What and how do students learn? Educational Psychology Review, 16 (3), 235-266.

Hmelo-Silver, C.E., \& Barrows, H.S. (2006). Goals and strategies of a problem-based learning facilitator. Interdisciplinary Journal of Problem-based Learning, 1 (1), 21-39.

Holloway, S. M., \& Gouthro, P. A. (2011). Teaching resistant novice educators to be critically reflective, Discourse. Studies in the Cultural Politics of Education, 32(1), 29-41.

Husu, J., Toom, A., \& Patrikainen, S. (2008) Guided reflection as a means to demonstrate and develop student teachers' reflective competencies. Reflective Practice, 9(1), 3751

Komur, S. (2010). Teaching knowledge and teacher competencies: A case study of Turkish preservice English teachers. Teaching Education, 21(3), 279-296.

Lee, H. J. (2005). Understanding and assessing preservice teachers' reflective thinking. Teaching and Teacher Education, 21(6), 699-715.

Lee, I. (2007). Preparing pre-service English teachers for reflective practice. ELT Journal, 61(4), 321-329.

Leijen, Ä., Allas, R., Toom, A., Husu, J., Marcos, J., Meijer, P., Knezic, D., Pedaste, M., \& Krull, E. ( 2014 ). Guided reflection for supporting the development of student teachers' practical knowledge. Procedia - Social and Behavioral Sciences (112) $314-322$

Leijen, Ä., Valtna, K., Leijen, D. A. J. \& Pedaste, M. (2012). How to determine the quality of students' reflections? Studies in Higher Education, 37(2), 203-217. 
Marcos, M. J., Sanchez, E., \& Tillema, H. H. (2011). Promoting teacher reflection: What is said to be done. Journal of Education for Teaching, 37(1), 21-36.

Mirzaei, F., Phang, F. A. , Kashefi, H. (2014). Measuring Teachers Reflective Thinking Skills. Procedia - Social and Behavioral Sciences (141) 640 - 647

Procee, H. (2006). Reflection in education: A Kantian epistemology. Educational Theory, 56(3), 237-253.

Reynolds, M. (2011). Reflective practice: Origins and interpretations. Action Learning: Research and Practice, 8(1), 5-13.

Rieger, A., Radcliffe, B. J., \& Doepker, G. M. (2013) Practices for Developing Reflective Thinking Skills Among Teachers. Kappa Delta Pi Record, 49(4), 184-189.

Rodgers, C. (2002). Defining reflection: Another look at John Dewey and reflective thinking. Teachers College Record, 104(4), 842-866.

Romano, M., \& Schwartz, J. (2005). Exploring technology as a tool for eliciting and encouraging beginning teacher reflection. Contemporary Issues in Technology and Teacher Education, 5(2), 149-168.

Sulistiyo, U. (2015). Improving English as a foreign language teacher education in Indonesia: The case of Jambi University. ( $\mathrm{PhD}$ thesis), RMIT University, Australia.

Torp, L., \& Sage, S. (2002). Problems as Possibilities: Problem-Based Learning for K-12 Education, 2nd edition. Alexandria, Virginia: ASCD.

Welsch, R. G., \& Devlin, P. A. (2007). Developing preservice teachers' reflection: Examining the use of video. Action in Teacher Education, 28(4), 53-61.

Zhu, H. (2014). Reflective thinking on EFL classroom discourse. Journal of Language Teaching and Research, 5(6), 1275-1282. 